\title{
IMPACT OF ICT INVESTMENTS ON PERFORMANCE OF COMPANIES IN TRANSITION ECONOMIES: EVIDENCE FROM CZECH REPUBLIC, HUNGARY AND SLOVAKIA
}

\author{
DOI: 10.12776/QIP.V17I2.232
}

\author{
FRANTIŠEK JANKE, MIROSLAVA PACKOVÁ
}

\section{INTRODUCTION}

Information and Communication Technologies (ICT) play a crucial role in business development and help companies become competitive, what is essential for surviving turbulent market conditions we face nowadays. United Nations Development Programme (UNDP) characterized ICT's as basically informationhandling tools, a varied set of goods, applications and services that are used to produce, store, process, distribute and exchange information. This definition contains a wide range of tools, all implemented with the aim to increase the efficiency of processes, and acting as a resource for decision making in different areas, e.g. relations among businesses (Janke, Prídavok, 2012) or within internal planning (Gavurová, 2011, 2012). There is a number of studies dedicated to the topic ICT adoption impact on firms' performance. Almost all studies were realized within developing and developed countries (Schreyer, 2000; Van Reen et al., 2010; Brynjolfsson and Yang, 1996; OECD, 2003) ommiting the transition economies. However, small number of studies make an evidence of ICT adoption impact on companies' performance in transition economies, supporting the thesis of the importantance of ICT as a tool for business development and increasing of competitiveness and performance (Delina and Tkáč, 2010; Dorčák and Delina, 2011; Roztocki and Weistroffer, 2008).

The transition economy can be defined as the economy in a process of a moving from a centrally planned to a driven market economy (Koyame-Marsch, 2011). The pre-1989 socialist countries of Central and Eastern Europe, isolated from other parts of the world, may serve as a good examples of such economies. All segments of their international economic cooperation, including trade, investment and technology flows, were predominantly occupied with intra-Soviet bloc (Mrak, 2000). When shifting from centrally planned to a market driven economy the former state-owned companies changed into the companies owned by individuals, had to overcome the lack of capital and technology in order to get 
competitive when comparing them to companies from developed countries. It is obvious that in this shifting process, foreign investment played very important role. Therefore many privatizations and restructuralizations of large state-owned companies by multinational companies took place. As the result, these privatizations increased the export performance and brought needed financial capital, know-how and technology to these regions (Ferencikova, 1997). Consequently, not merely financial capital, but also ICT investments have been identified as a very important tool of progress in this process as they have a signigicant impact on performance of companies (Dobija et al., 2012), (Delina et al., 2013).

When assessing the impact of ICT on companies' performance, different variables may serve as performance indicator. In this study the stock market performance approach was used.The purpose of this study is to show evidence of stock market reaction to ICT investment in three chosen transition economies: Czech Republic, Hungary and Slovakia. This study follows the study conducted by Dobija et al. (2012) and Delina et al. (2013). Study by Dobija et al. (2012) investigated stock market reaction to IT investment announcements in Poland. On the other hand, study conducted by Delina et al. (2013) investigated stock market reaction to IT investment announcements in Czech Republic, Hungary and Slovakia as a whole region, not studying the differences among these three contries. In this study, each of the chosen transitioneconomies from 'Visegrad' region will be investigated separately with the aim to understand similarities and differences among them.

\section{METHODOLOGY}

The approach used in this study is based on the Efficient Market Hypothesis developed by Eugen Fama (1960). Fama claims that the prices of financial assets reflect all relevant market information. Therefore prices in average are accurate, which means that financial markets are efficient (Harder, 2010).

To assess the corporate dealings from an investor's point of view we used the approach of unexpected changes in stock prices. To recognize whether there are unexpected changes in stock prices as a consequence of the event, the concept of abnormal returns (ARs), or excess returns, is commonly used (Peterson, 1989), (Henderson, 1990). This concept is based on the OLS (ordinary least squares) model, suggested by Fama, Fisher, Jensen and Roll (1969) in their study of stock splits:

$R_{i t}^{*}=\alpha_{i}+\beta_{i} R_{m t}+\mu_{i t}$ for $t=1,2, \ldots T$

where

$R_{i t}^{*} \quad=$ Return on security $\mathrm{i}$ for period $\mathrm{t}$;

$R_{m t}=$ Return on market index for period $\mathrm{t}$; 
$\alpha_{i} \quad=$ Intercept;

$\beta_{i} \quad=$ Slope coefficient;

$\mu_{i t} \quad=$ Disturbance term; and

$\mathrm{T} \quad=$ Number of periods in the estimation period.

Then the excess return (also referred to as the abnormal stock return or the prediction error) for an individual security for a given period is the difference between the observed return for that period and the expected or predicted return for that period:

$A R_{i t}=R_{i t}-R_{i t}^{*}$

To reflect statistical error in the determination of expected returns the analysis requires the standardisation of abnormal returns:

$S A R_{i t}=\frac{A R_{i t}}{S D_{i t}}$

where

$S D_{i t}=$ standard deviation of residual returns for company $\mathrm{i}$ in period $\mathrm{t}$.

Finally, to assess the stock price reaction for significance, cumulative standardized abnormal returns (CSARs) and Z-value for a particular event window have been used:

$\operatorname{CSAR}_{t}=\sum_{i=t_{1}}^{t_{2}} \frac{S A R_{i t}}{\sqrt{t_{2}-t_{1}+1}}$

$Z=\frac{\sum_{t=1}^{N} \operatorname{CSAR} t}{\sqrt{N}}$

where

$\mathrm{N}=$ number of events.

If $\mathrm{Z}$ value is higher than 2.575 , reaction is significant at $1 \%$ level (***). $\mathrm{Z}$-value ranging from 1.96 to 2.575 indicates significance at $5 \%$ level $(* *)$, from 1.645 to 1.96 indicates significance at $10 \%$ level (*) and for Z-value lower than 1.645 the results are not significant.

In the literature there is no evidence, of how many days the estimation period should consist of, but it should be in range from 50 to 250 days. In order to compare our results to those from study by Dobija et al. (2012), the same estimation period starting 270 days before event ending 20 days after the event has been used. 


\section{Event window used}

The previous studies used short event window containing two or three day period (Peterson, 1989). As pointed by Dobija et al. (2012) for transition economies longer event window should be used as significant results were found also in a window containing 20 days before and 5 days after the announcement. In this study four event windows have been used. Two day window containing day before announcement and announcement day [-1,0]; three day window starting day before and ending day after the announcement [-1,1]; 21 event window ranging from 15 days before to 5 days after event $[-15,5]$ and the longest 26 days window starting 20 days before the event and ending 5 days after this event [-20,5]. For all event windows research hypotheses have been tested.

\section{Research Hypotheses}

As this study followed the study conducted by Dobija et al. (2012) and Delina et al. (2013), the same hypotheses were used (H1-H5). These hypotheses are based on an explanatory model that was used by Roztocki and Weistroffer (2009). Furthermore we added two new hypotheses (H6, H7):

H1: The stock market will react more positively to ICT investment announcements when the system is acquired from a global, large vendor, as compared to a small, local vendor.

H2: The stock market will react more positively to announcements of ICT investments when the investments are announced by companies with high beta value, as compared to similar announcements by companies with low beta value.

H3: The stock market will react more positively to ICT investment announcements conducted during a bull market, as compared with similar investments under descending market or bear market conditions.

H4: The stock market will react more positively to announcements of completed ICT investments, than to announcements of planned projects or projects inprogress.

H5: There will be a difference in stock market reaction, when the investment is announced in local language and targeted at existing shareholders, as compared to announcements made in English and targeting global prospective investors.

H6: The stock market will react more positively to ICT investment announcement before crisis arose as compared to similar announcement in after crisis time.

Financial crisis that started in year 2008 has significantly influenced stock market performance, in the wake of the collapse of Lehman Brothers the stock market reacted sharply around the globe (Senbet and Gande, 2009; Becchetti and Ciretti, 2011). In consideration of influence of an economic cycle we assume more positive reaction to ICT investment in time before crisis started as a consequence of a pessimistic perceives during after crisis times. 
H7: The stock market will react more positively to ICT investment announcement, when the announcements are made by companies traded on a stock exchange for more than ten years, as compared to similar announcements made by companies traded on a stock exchange for less than ten years.

Trust into company and their future performance are related to company's length of existence or trade on a stock exchange. Companies, which run a business on the market or are traded on stock exchange for a longer time, are perceived as the more trustworthy. Supporting this psychological effect, we claim, that companies traded for more than ten years will react more positively to ICT investment announcement.

\section{Data}

Data sample consisted of the announcements from the year 1998 to 2013. The latest announcement is from February 2013, as data collection was finished in March 2013. The similar data sample as in study by Delina et al. (2013) have been used. In Czech Republic 46 announcements, in Hungary 40 and in Slovakia only 9 announcements were found.

\section{RESULTS}

\section{Case of Hungary}

When we look at the whole sample, not dividing it into subsamples (Table 1), we can find positive significant reaction in three of four event window. That means, that in Hungary, companies traded on a Budapest stock exchange react positively to ICT investment announcement. The role of ICT is in these companies was confirmed as an announcement related to ICT investment is followed by increase of their stock prices. Additionally, we have divided the whole sample into subsamples related to hypothesis we postulated.

Regarding hypothesis 1, where the impact of ICT announcement according to type of vendor tested, the positive significant reaction for global vendorin [-20,5] event window was found.

In hypothesis 2, we tested how beta factor of companies affects the reaction to ICT investment. The significant positive reaction for the companies with beta factor higher than 0,9 for event window containing 15 days before and 5 days after the event was showed.

To analyse hypothesis 3 we divided whole sample into three subsamples according to market conditions: bull, bear and descending market. To define the market conditions, stock market indexes have been used. For Czech Republic we used PX index, for Hungary BUX and for Slovakia SAX index. Bull market was defined as a market of rising index by more than $20 \%$ or longer than 2 months, bear market - vice versa. By descending market, the market with failing indexes 
up to $20 \%$ of their last peak value. In Hungarian economy we found significant positive reaction almost for each event window, except the window containing day before and day of ICT investment announcement.

When testing hypothesis 4, investments in progress/future showed significance for one event window. Possible explanation for this result could be that in companies with ICT investment in progress or future investment, there is a positive investors' expectation from that make stock prices move up. Investors assume the increase of the stock prices when releasing the announcement related to completition of ICT investment and buy stocks before ICT investment is completed pushing the stock prices up.

In hypothesis 5 we claimed that reaction to ICT investment is more positive when announcement is published in a local language. This statement was supported in two event windows.

Additionally we have added and tested 2 new hypotheses. In the first one, hypothesis 6 , we tested the impact of length of trade on stock market reaction to ICT investments announcements. As the cut-off line we used 10 years length of trade. Companies that are being traded on a stock exchange for more than 10 years showed positive significant reaction to ICT investment announcement in three event window.

The last tested hypothesis, hypothesis 7 , is related to the influence of crisis that started in year 2008. In this hypothesis we claim, that stock market will react more positively to ICT announcement announced before crisis arose. This statement is related to hypothesis 3 taking into account the fact, that after crisis all stock indexes declined and we could identify bear market on each market and pessimistic moods. However, the results were surprising. We found positive significance for the announcement released after crisis. One possible explanation could be, that after the crisis, each development of company, even the small one, can be perceived by investors as a sign that company is in good financial situation and is able to finance investments and might grow in the future. 
Table 1 - Summary of results from Hungary

\begin{tabular}{|c|c|c|c|c|c|c|c|c|c|c|c|c|}
\hline \multirow{2}{*}{ Sample/subsample } & \multicolumn{3}{|c|}{$[-20,5]$} & \multicolumn{3}{|c|}{$[-15,5]$} & \multicolumn{3}{|c|}{$[1,1]$} & \multicolumn{3}{|c|}{$[-1,0]$} \\
\hline & $\mathbf{N}$ & CSAR & $\mathbf{Z}$ & $\mathbf{N}$ & CSAR & $\mathbf{Z}$ & $\mathbf{N}$ & CSAR & $\mathbf{Z}$ & $\mathbf{N}$ & CSAR & $\mathbf{Z}$ \\
\hline full sample & 40 & 0.448 & $2.830 * * *$ & 40 & 0.351 & $2.220 * *$ & 40 & 0.415 & $2.623 * * *$ & 40 & 0.209 & 1.320 \\
\hline \multicolumn{13}{|c|}{ breakdown by vendor } \\
\hline local & 2 & -0.023 & -0.033 & 2 & 0.115 & 0.163 & 2 & 0.489 & 0.692 & 2 & 0.439 & 0.621 \\
\hline global & 23 & 1.308 & $1.749 *$ & 23 & 1.235 & 1.386 & 23 & 1.115 & 0.784 & 23 & 1.064 & 0.530 \\
\hline \multicolumn{13}{|c|}{ breakdown by company } \\
\hline beta $<0,9$ & 18 & 0.406 & $1.720^{*}$ & 18 & 0.296 & 1.254 & 18 & 0.438 & $1.858 *$ & 18 & 0.112 & 0.473 \\
\hline beta $>=0,9$ & 22 & 0.482 & $2.260 * *$ & 22 & 0.397 & $1.860 *$ & 22 & 0.396 & $1.856 *$ & 22 & 0.288 & 1.352 \\
\hline \multicolumn{13}{|c|}{$\begin{array}{l}\text { breakdown by market } \\
\text { conditions }\end{array}$} \\
\hline bull & 35 & 0.445 & $2.635 * * *$ & 35 & 0.363 & $2.147 * *$ & 35 & 0.396 & $2.343 * *$ & 35 & 0.186 & 1.101 \\
\hline descending & 3 & 0.256 & 0.444 & 3 & 0.188 & 0.326 & 3 & 0.778 & 1.347 & 3 & 0.365 & 0.633 \\
\hline bear & 2 & 0.773 & 1.094 & 2 & 0.390 & 0.551 & 2 & 0.196 & 0.277 & 2 & 0.368 & 0.521 \\
\hline \multicolumn{13}{|c|}{$\begin{array}{l}\text { breakdown by investment } \\
\text { status }\end{array}$} \\
\hline in-progress/future & 6 & 0.971 & $2.378 * *$ & 6 & 0.915 & $2.242 * *$ & 6 & 0.940 & $2.303 * *$ & 6 & 0.487 & 1.193 \\
\hline completed & 33 & 0.331 & $1.902 *$ & 33 & 0.217 & 1.244 & 33 & 0.333 & $1.911 *$ & 33 & 0.168 & 0.965 \\
\hline \multicolumn{13}{|c|}{$\begin{array}{l}\text { breakdown by announcement } \\
\text { language }\end{array}$} \\
\hline english & 5 & 0.700 & 1.565 & 5 & 0.530 & 1.185 & 5 & 1.140 & $2.549 * *$ & 5 & 0.455 & 1.017 \\
\hline local & 34 & 0.390 & $2.272 * *$ & 34 & 0.294 & $1.713^{*}$ & 34 & 0.321 & $1.873 *$ & 34 & 0.182 & 1.062 \\
\hline \multicolumn{13}{|c|}{ breakdown by length of trade } \\
\hline less than 10 years & 10 & 0.211 & 0.668 & 10 & 0.179 & 0.565 & 10 & 0.343 & 1.084 & 10 & 0.022 & 0.069 \\
\hline more than 10 years & 29 & 0.553 & $2.869 * * *$ & 29 & 0.397 & $2.139 * *$ & 29 & 0.443 & $2.385 * *$ & 29 & 0.281 & 1.515 \\
\hline \multicolumn{13}{|l|}{ breakdown by crisis } \\
\hline before crisis & 5 & 0.219 & 0.489 & 5 & 0.2454 & 0.5487 & 5 & 0.829 & $1.853 *$ & 5 & 0.160 & 0.378 \\
\hline after crisis & 35 & 0.480 & $2.841 * * *$ & 35 & 0.3662 & $2.167 * *$ & 35 & 0.356 & $2.104 * *$ & 35 & 0.214 & 1.268 \\
\hline
\end{tabular}

\section{Case of Czech Republic}

When we look at the results of companies in Czech Republic, we can see only negative significant reactions and these are related to only two event windows $[-20,5],[-15,5]$. Positive reaction, shown in the Table 2, is not significant. Negative significant reaction has been found in mentioned event windows in different samples - in a whole sample, in companies having beta factor lower than 0.9, that acquired system from a global vendor, that announced ICT investment during descending market or after crisis started up, that announced ICT investment in local language and also for companies with completed ICT investments or for companies traded less than 10 years. Interesting thing is, that for the Czech Republic in almost each postulated hypothesis, we did not confirm hypothesis in expected possitive way. That means, we did not find any positive significant reaction for a category in subsample, but we found negative significant reaction for the other category within the same subsample (except hypothesis 4 and 5). In regard to these results we can claim, that stock market performance of Czech publicly traded companies reacts rather negative to ICT investment announcements under disadvantageous conditions as compare to positive reaction under auspicious conditions. This conclusion counts almost for all hypothesis we tested, except hypothesis 4, where we didn't confirm that 
announcements of completed ICT investment will affect the stock market reaction more positively in contrast to announcements of ICT investments in progress or future investments. This confirmed the findings from Hungary.

Also hypothesis 5 wasn't supported, as we didn't find any positive reaction to ICT investments released in a local language. That means that investors perceive more positively the announcements released in English, in contrast to local language.

Table 2 - Summary of results from Czech Republic

\begin{tabular}{|c|c|c|c|c|c|c|c|c|c|c|c|c|}
\hline \multirow{2}{*}{ Sample/subsample } & \multicolumn{3}{|c|}{$[-20,5]$} & \multicolumn{3}{|c|}{$[-15,5]$} & \multicolumn{3}{|c|}{$[-1,1]$} & \multicolumn{3}{|c|}{$[1,0]$} \\
\hline & $\mathbf{N}$ & CSAR & $\mathbf{Z}$ & $\mathbf{N}$ & CSAR & $\mathbf{Z}$ & $\mathbf{N}$ & CSAR & $\mathbf{Z}$ & $\mathbf{N}$ & CSAR & $\mathbf{Z}$ \\
\hline full sample & 46 & -0.356 & $-2.415 * *$ & 46 & -0.33 & $-2.241 * *$ & 46 & 0.015 & 0.102 & 46 & -0.059 & -0.402 \\
\hline \multicolumn{13}{|l|}{ breakdown by vendor } \\
\hline local & 5 & -0.668 & -1.493 & 5 & -0.471 & -1.053 & 5 & 0.533 & 1.192 & 5 & 0.444 & 0.992 \\
\hline global & 15 & 0.455 & $-1.995 * *$ & 15 & 0.516 & $-1.741 *$ & 15 & 0.762 & -0.724 & 15 & 0.566 & -1.537 \\
\hline \multicolumn{13}{|c|}{ breakdown by company } \\
\hline beta $<0,9$ & 22 & -0.691 & $-3.239 * * *$ & 22 & -0.655 & $-3.071 * * *$ & 22 & -0.088 & -0.411 & 22 & -0.108 & -0.504 \\
\hline beta $>=0,9$ & 24 & -0.049 & -0.242 & 24 & -0.033 & -0.163 & 24 & 0.109 & 0.535 & 24 & -0.015 & -0.074 \\
\hline \multicolumn{13}{|c|}{$\begin{array}{l}\text { breakdown by market } \\
\text { conditions }\end{array}$} \\
\hline bull & 30 & -0.177 & -0.97 & 30 & -0.191 & -1.045 & 30 & 0.041 & 0.225 & 30 & -0.153 & -0.837 \\
\hline descending & 10 & -0.751 & $-2.374 * *$ & 10 & -0.652 & $-2.060 * *$ & 10 & -0.121 & -0.382 & 10 & 0.027 & 0.085 \\
\hline bear & 6 & -0.593 & -1.452 & 6 & -0.494 & -1.209 & 6 & 0.111 & 0.272 & 6 & 0.265 & 0.648 \\
\hline \multicolumn{13}{|c|}{$\begin{array}{l}\text { breakdown by investment } \\
\text { status }\end{array}$} \\
\hline in-progress/future & 11 & -0.38 & -1.259 & 11 & -0.281 & -0.932 & 11 & -0.205 & -0.681 & 11 & -0.313 & -1.039 \\
\hline completed & 35 & -0.349 & $-2.063 * *$ & 35 & -0.346 & $-2.047 * *$ & 35 & 0.084 & 0.499 & 35 & 0.021 & 0.122 \\
\hline \multicolumn{13}{|c|}{$\begin{array}{l}\text { breakdown by announcement } \\
\text { language }\end{array}$} \\
\hline english & 11 & 0.061 & 0.201 & 11 & 0.014 & 0.045 & 11 & 0.07 & 0.234 & 11 & -0.118 & -0.39 \\
\hline local & 16 & -0.786 & $-3.143 * * *$ & 16 & -0.761 & $-3.045 * * *$ & 16 & 0.052 & 0.207 & 16 & 0.113 & 0.45 \\
\hline \multicolumn{13}{|c|}{ breakdown by length of trade } \\
\hline less than 10 years & 12 & -0.542 & $-1.877 *$ & 12 & -0.661 & $-2.291 * *$ & 12 & -0.034 & -0.118 & 12 & -0.025 & -0.088 \\
\hline more than 10 years & 34 & -0.291 & $-1.694 *$ & 34 & -0.214 & -1.246 & 34 & 0.032 & 0.189 & 34 & -0.071 & -0.416 \\
\hline \multicolumn{13}{|l|}{ breakdown by crisis } \\
\hline before crisis & 6 & 0.442 & 1.082 & 6 & 0.208 & 0.508 & 6 & 0.2369 & 0.58 & 6 & 0.115 & 0.282 \\
\hline after crisis & 40 & -0.476 & $-3.008 * * *$ & 40 & -0.411 & $-2.600 * * *$ & 40 & -0.0183 & -0.116 & 40 & -0.085 & -0.54 \\
\hline
\end{tabular}

\section{Case of Slovakia}

As we can see in Table 3, none of results were significant in Slovakia neither for a whole sample, nor for subsample broken by vendor. Beta factor higher than 0.9 was positively significant for the event window containing day before and day after the announcement. Beta factor lower than 0.9 was found to be negatively significant for the window starting 20 days before event and ending 5 days after it. For the same event window, negative significance in descending market and English language of the announcements can be seen. As a sample from Slovakia contained only 9 announcement there were no announcement of completed ICT investments. Also in the other subsamples there were just a few announcements released. Negative significant reaction, which was found in Slovak sample, confirmed the results from Czech Republic. 
Table 3 - Summary of results from Slovakia

\begin{tabular}{|c|c|c|c|c|c|c|c|c|c|c|c|c|}
\hline \multirow{2}{*}{ Sample/subsample } & \multicolumn{3}{|c|}{$[-20,5]$} & \multicolumn{3}{|c|}{$[-15,5]$} & \multicolumn{3}{|c|}{$[-1,1]$} & \multicolumn{3}{|c|}{$[-1,0]$} \\
\hline & $\mathbf{N}$ & CSAR & $\mathbf{Z}$ & $\mathbf{N}$ & CSAR & $\mathbf{Z}$ & $\mathbf{N}$ & CSAR & $\mathbf{Z}$ & $\mathbf{N}$ & CSAR & $\mathbf{Z}$ \\
\hline full sample & 9 & -0.267 & -0.801 & 9 & 0.081 & 0.244 & 9 & 0.457 & 1.37 & 9 & 0.158 & 0.473 \\
\hline \multicolumn{13}{|c|}{ breakdown by vendor } \\
\hline local & 2 & 0.175 & 0.248 & 2 & -0.001 & -0.002 & 2 & 0.591 & 0.836 & 2 & -0.351 & -0.496 \\
\hline global & 2 & 0.979 & 0.663 & 2 & 0.919 & 0.535 & 2 & 1.058 & 0.83 & 2 & 0.991 & 0.687 \\
\hline \multicolumn{13}{|c|}{ breakdown by company } \\
\hline beta $<0,9$ & 5 & -0.844 & $-1.887 *$ & 5 & -0.028 & -0.062 & 5 & 0.091 & 0.204 & 5 & -0.029 & -0.065 \\
\hline beta $>=0,9$ & 4 & 0.454 & 0.909 & 4 & 0.218 & 0.435 & 4 & 0.914 & $1.828 *$ & 4 & 0.392 & 0.783 \\
\hline \multicolumn{13}{|c|}{$\begin{array}{l}\text { breakdown by market } \\
\text { conditions }\end{array}$} \\
\hline bull & 3 & -0.06 & -0.103 & 3 & -0.27 & -0.468 & 3 & 0.71 & 1.229 & 3 & 0.05 & 0.087 \\
\hline descending & 2 & -2.785 & $-3.938 * * *$ & 2 & -0.732 & -1.035 & 2 & -0.1 & -0.142 & 2 & -0.128 & -0.181 \\
\hline bear & 4 & 0.836 & 1.672 & 4 & 0.751 & 1.503 & 4 & 0.546 & 1.091 & 4 & 0.381 & 0.762 \\
\hline \multicolumn{13}{|c|}{$\begin{array}{l}\text { breakdown by investment } \\
\text { status }\end{array}$} \\
\hline in-progress/future & 0 & - & - & 0 & - & - & 0 & - & - & 0 & - & - \\
\hline completed & 5 & -0.464 & -1.038 & 5 & 0.291 & 0.652 & 5 & 0.43 & 0.96 & 5 & 0.008 & 0.017 \\
\hline \multicolumn{13}{|c|}{$\begin{array}{l}\text { breakdown by announcement } \\
\text { language }\end{array}$} \\
\hline english & 2 & -1.556 & $-2.120 * *$ & 2 & 0.494 & 0.698 & 2 & 0.531 & 0.751 & 2 & -0.148 & -0.209 \\
\hline local & 3 & 0.263 & 0.456 & 3 & 0.156 & 0.271 & 3 & 0.362 & 0.626 & 3 & 0.111 & 0.193 \\
\hline \multicolumn{13}{|c|}{ breakdown by length of trade } \\
\hline less than 10 years & 3 & -0.642 & -1.112 & 3 & -0.798 & -1.382 & 3 & 0.22 & 0.38 & 3 & -0.151 & -0.262 \\
\hline more than 10 years & 6 & -0.079 & -0.195 & 6 & 0.521 & 1.276 & 6 & 0.575 & 1.409 & 6 & 0.312 & 0.765 \\
\hline \multicolumn{13}{|l|}{ breakdown by crisis } \\
\hline before crisis & 5 & -0.392 & -0.876 & 5 & -0.583 & -1.304 & 5 & 0.575 & 1.286 & 5 & 0.067 & 0.15 \\
\hline after crisis & 4 & -0.111 & -0.223 & 4 & 0.912 & $1.824 *$ & 4 & 0.309 & 0.617 & 4 & 0.271 & 0.542 \\
\hline
\end{tabular}

\section{Comparison of 'Visegrad' countries}

According to results, we can provide the comparison of hypotheses confirmation in four transition economies forming Visegrad: Czech Republic, Hungary, Poland and Slovakia. To support hypothesis of significant reaction to announcements, the occurence in at least three event windows was needed. When significance has been shown in one or two windows, hypothesis was supported only partially. As can be seen in Table 4, "global vendors" announcements were significance only in Poland and partially in Hungary, though the result was limited to only one event window. Two other countries samples didn't support these findings. Beta factor was significant in Czech Republic and Slovakia, eventhough just partially. Unlike the study by Dobija et al. (2012), in our study, market conditions showed significance in Hungary and partially in Czech Republic and Slovakia. On the other hand in Dobija et al. (2012), the partial significance for completed ICT investments has been found, whereas in other tree countries we cannot confirm that. The language of announcement was significant for each country except Czech Republic. Length of trade and crisis didn't show any significance only in Slovakia. 
Table 4 - Comparison of results in countries of Visegrad

\begin{tabular}{|ccccc|}
\hline Hypothesis & $\begin{array}{c}\text { Supported in } \\
\text { Poland (Dobija } \\
\text { study) }\end{array}$ & $\begin{array}{c}\text { Supported in } \\
\text { Hungary }\end{array}$ & $\begin{array}{c}\text { Supported in } \\
\text { Czech Republic }\end{array}$ & $\begin{array}{c}\text { Supported in } \\
\text { Slovakia }\end{array}$ \\
1 & Yes & Partially & No & No \\
2 & No & No & Partially & Partially \\
3 & No & Yes & Partially & Partially \\
4 & Partially & No & No & No \\
5 & Partially & Partially & No & Partially \\
6 & - & Yes & Partially & No \\
7 & - & Partially & Partially & No \\
\hline
\end{tabular}

\section{CONCLUSION}

The results of investigation related to the impact of ICT investment announcement to stock market reaction in three transition economies: Czech Republic, Hungary and Slovakia and their comparison to the results of study by Dobija et al. (2012) highlight some similarities on one hand, but also point out some differences on the other hand. When we compared study by Dobija et al. (2012) with our results, the closest to Polish results are the ones from Hungary. On the other hand, other two Visegrad countries, Czech Republic and Slovakia, provides similar results as well, although they are in contrast to Polish and Hungarian. This conclusion is not surprising when we take into account that Czech republic and Slovakia used to form common country - Czechoslovakia. These differences and similarities among the transition countries already existed before the transition started as a consequence of historical background. For example in Hungary and Poland, private ownership was allowed while it was forbidden in Czech Republic and Slovakia, what influenced the speed and running of the privatisation. Moreover, differences in results can be influenced by transition process chosen - particularly differences in the choice of the privatization method, the speed of transition or government reform policies undertaken during transition (Hellström, 2009), (Donnorummo, 2006). These are some of many reasons why economy situation in these countries is different and thus also why the impact of ICT investments in these economies is not the same.

This study should contribute to literature and research focused on ICT investments and their impact on firms in transition economies and may act as the basis for comparison of these Visegrad economies with other transition economies.

\section{ACKNOWLEDGEMENT}

This work was supported by the national project VEGA 1/1042/12 "Stockmarket reaction to IT investments: Evidence from the Visegrád Countries"financed by Ministry of Education, Science, Research and Sport of the Slovak Republic. 


\section{REFERENCES}

Becchetti, L. and Ciciretti, L., 2011. Stock Market Reaction to the Global Financial Crisis: testing for the Lehman Brothers'Event. Giornale degli Economisti, 2011, 70(2), pp. 3-58.

Brynjolfsson, E. and Yang, S.,1996. Information Technology and Productivity: A Review of the Literature. Advances inComputers, Academic Press, 43, pp. 179214.

Delina, R., Packová, M., Roztocki, N. and Weistroffer, H.R., 2013. Information Technology Investments and Stock Market Reaction: Evidence from Czech Republic, Hungary and Slovakia. Proceedings of the Second International Conference on ICT (ICTM 2013). Wroclaw, Poland, 16-17 September, 2013, pp. 98-105. ISBN 978-83-64-389-00-9.

Delina, R. and Tkac, M., 2010. The Impacts of Specific ICT Solutions on Productivity. IDIMT-2010 Information Technology - Human Values, Innovation and Economy. Linz: Trauner, 2010, ISBN 978-3-85499-760-3.

Dobija, D., Klimczak, K.M., Roztocki, N. and Weistroffer, H.R., 2012. Information technology investment announcements and market value in transition economies: Evidence from Warsaw Stock Exchange, The Journal of Strategic Information Systems, 21 (4), pp. 308-319.

Donnorummo, B., 2006. The Political and Economic Complexities of Transition. Keynotes Address, Zagreb International Review of Economics and Business, Special Conference Issue, pp. 13-27.

Dorčák, P. and Delina, R., 2011. Impact of Emarketing Services on Economic Performance. Journal of Economics. Vol. 59, No. 1 (2011), pp. 44-58. ISSN 0013-3035.

Ferencikova, S., 1997. East West Join Ventures in a Transitional Economy: Case of Slovakia. The William Davidson Institute, Michigan. Available at: <http://deepblue.lib.umich.edu/bitstream/handle/2027.42/39417/wp27.pdf?seque nce $=3>$ [Accessed 25 October 2013].

Gavurová, B., 2012. Source Identification of Potential Malfunction of Balanced Scorecard System and Its Influence on System Function, Ekonomie a management,15(3), pp. 76-90. ISSN 1212-3609.

Gavurová, B., 2011. Systém Balanced Scorecard v podnikovom riadení. Ekonomický časopis, 59 (2), pp. 163-177. ISSN 0013-3035.

Harder, S., 2008. The Efficient Market Hypothesis and its Application to Stock Markets, GRIN Verlag, ISBN 978-3-640-74376-6.

Hellström, K., 2009. Financial Accounting Quality in a European Transition Economy: The Case of the Czech Republic. Stockholm School of Economics, ISBN 978-91-7258-780-9. 
Henderson, J. and Glenn, V., 1990. Problems and solutions in conducting event studies. The Journal of Risk and Insurance, 57 (2), pp. 282-306.

Janke, F. and Prídavok, M., 2012. B2B network performance: practical aspects of network supply adequacy. IDIMT-2012: ICTSupport for Complex Systems : 20th Interdisciplinary Information ManagementTalks: Jindřichův Hradec, Sept. 12-14, 2012, Czech Republic, Linz: Trauner Verlag, 2012, pp. 337-346. ISBN 978-399033-022-7.

Koyame-Marsh, R.O., 2011. The Complexities of Economic Transition: Lessons from the Czech Republic and Slovakia. International Journal of Business and Social Science, 2 (19), pp.71-85.

Mrak, M., 2000. Globalization: Trends, Challenges and Opporturnites for Countries in Transtition, UNIDO, Vienna 2000. Available at: <http://www.unido.org/fileadmin/import/userfiles/puffk/mrak.pdf> [Accessed 2 November 2013].

OECD, 2003. ICT and Economic Growth: Evidence from OECD Countries, Industries and Firms. ISBN 92-64-10128-4.

Peterson, P.P., 1989. Event Studies: A Review of Issues and Methodology, Quarterly Journal of Business and Economics, 28, pp. 36-66.

Roztocki, N. and Weistroffer, H.R., 2009. Stock Market Reaction to Information Technology Investments: Towards an Explanatory Model, 17th European Conference on Information Systems (ECIS 2009), Verona, Italy.

Roztocki, N. and Weistroffer, H.R., 2008. Stock Price Reaction to Investments in EAI and ERP: A Comparative Event Study, 4lth Hawaii International Conference on System Sciences (HICSS 2008). Big Island, Hawaii, USA.

Senbet, L.W. and Gande, A., 2009. Financial Crisis and Stock Markets: Issues, Impact, and Policies. Dubai Economic Council "Financial Crisis, Its Causes, Implications, and Policy Responses”, Dubai, October 2009.

Schreyer, P., 2000. The Contribution of Information and Communication Technology to Output Growth: A Study of the G7 Countries, OECD Publishing.

Van Reenen, J., Bloom, N., Draca, M., Kretschmer,T., Sadun,R., Overman, H. and Schankerman, M., 2010. The Economic Impact of ICT, Final Report, Centre for Economic Performance, London School of Economics, London. 


\section{ABOUT THE AUTHORS}

Ing. František Janke, PhD., Assistant at Technical University of Košice, Faculty of Economics, Department of Banking and Investments, Němcovej 32, 04001 Košice, Slovakia, e-mail: frantisek.janke@tuke.sk.

Ing. Miroslava Packová, PhD. student, Technical University of Košice, Faculty of Economics, Department of Banking and Investments, Němcovej 32, 04001 Košice, Slovakia, e-mail: miroslava.packova@tuke.sk. 